\title{
Determination of Minor and Trace Elements in Biogenic Carbonate Minerals of Coccolithophores by High-Resolution Inductively Coupled Plasma Mass Spectrometry
}

\author{
Hiroshi Hasegawa, ${ }^{*}$ Saeko Mito, ${ }^{\dagger}$ Kazuhiro Norisuye, ${ }^{\dagger}$ Masakazu Matsui, ${ }^{\dagger}$ Teruya Maki, and \\ Kazumasa Ueda
}

Department of Chemistry and Chemical Engineering, Faculty of Engineering, Kanazawa University, Kodatsuno, Kanazawa 920-8667

$\dagger$ Institute for Chemical Research, Kyoto University, Uji, Kyoto 611-0011

(Received June 6, 2002)

\begin{abstract}
The sample preparation and analytical methodology are described for determining minor and trace elements (Al, As, Ba, Cd, Co, Cr, Fe, Mg, Mn, Mo, Ni, Sb, Sr, U, V, W, Y and Zn) in biogenic carbonate minerals of coccolithophores. Coccolith particles isolated from cultivated coccolithophores were purified by centrifugation and resuspension with 0.5 $\mathrm{mM}$ sodium hydrogencarbonate solutions $\left(1 \mathrm{M}=1 \mathrm{~mol} \mathrm{~L}^{-1}\right)$. The concentrations of the elements in the final solutions were determined by high-resolution inductively coupled plasma mass spectrometry and inductively coupled plasma atomic emission spectrometry. The analytical results of coccolith particles suggest that the molar ratios of the minor and trace elements in coccoliths vary with the compositions of the medium in which the coccolithophores are grown.
\end{abstract}

Carbonate minerals are found over large areas of the ocean floor and are composed mostly of calcium carbonate. There has been a continued interest in the chemistry of minor and trace elements in calcium carbonate minerals, because the contents of minor and trace elements in natural carbonates may be useful as geochemical tracers for understanding the compositions of paleowaters. ${ }^{1,2}$ Most of these studies were performed on skeletons of foraminiferans, ${ }^{3,4}$ shells of macrobenthic $\operatorname{organisms}^{5-7}$ and laboratory-grown calcite by inorganic reactions. ${ }^{8,9}$ Carbonate sediments of the ocean floor are composed principally of planktonic skeletons which are produced by coccolithophores and foraminiferans. ${ }^{10,11}$ Coccolithophore calcification contributes a major portion of the calcite content in pelagic sediments, which influences the global carbon cycle in the ocean. ${ }^{12,13}$

Coccolithophores have oval plates of $\mathrm{CaCO}_{3}$, that is, coccoliths which are formed intracellularly in coccolith vesicles and are retained on the cell surfaces. ${ }^{14-16}$ Coccoliths contain small amounts of elements other than $\mathrm{CaCO}_{3}$. Fe, $\mathrm{Mg}, \mathrm{Sr}, \mathrm{Si}$ and $\mathrm{Zn}$ were qualitatively found in isolated coccoliths by X-ray fluorescence spectrometry. ${ }^{17}$ The determination of minor and trace elements in coccoliths is expected to provide useful information on the chemical condition where the coccoliths were formed, because the minor and trace elements would be incorporated into coccoliths in proportion to their concentration in the surrounding water. It is generally believed that trace elements in the carbonate shells of various organisms are related to the ambient seawater conditions. ${ }^{3,5}$ Recently, Stoll et al. reported that $\mathrm{Sr} / \mathrm{Ca}$ variations in coccolith sediments are valuable tools for gathering information about past climates and ocean productivity. ${ }^{18}$
For our studies to try to understand the behavior of some trace elements in coccoliths, a method was needed that allows the determination of trace elements down to $\mu \mathrm{g} \mathrm{g}^{-1}$ in very small amounts, as small as $20 \mathrm{mg}$ of $\mathrm{CaCO}_{3}$. Here, we report on a clean sample preparation and analytical methodology for quantitatively determining minor and trace elements in coccoliths. Coccolith samples were isolated from Emiliania huxleyi cultures, which were incubated in Eppley's media. E. huxleyi is a ubiquitous oceanic coccolithophore occurring in almost all of the world's oceans, except polar waters. ${ }^{19}$ In order to minimize contamination during sample treatment, a centrifugation technique was used for the purification of coccoliths. The concentrations of the elements were measured using high-resolution inductively coupled plasma mass spectrometry and inductively coupled plasma atomic emission spectrometry.

\section{Experimental}

Reagents. For the analysis of coccoliths, ultra-high purity nitric acid (TAMAPURE-AA-10, Tama Chemicals, Tokyo, Japan) was used without further purification. Metal standard solutions (1000 $\mathrm{mg} \mathrm{L}^{-1}$ ) were obtained from Wako (Osaka, Japan), and intermediate standard solutions were prepared by an appropriate dilution of $0.5 \mathrm{M} \mathrm{HNO}_{3}$. The preparation of solutions was carried out in a simple clean booth. Other reagents were of analytical reagent grade or better. All solutions were prepared with deionized water (MQW) using a MiliQ-II system (Millipore, Bedford, MA).

Cultivation of Coccolithophores. A culture of Emiliania huxleyi was kindly provided by Dr M. Okazaki (Department of Science Education, Tokyo Gakugei University, Japan). The stock cultures were maintained in Eppley's media ${ }^{20}$ using artificial seawater prepared according to Fleming ${ }^{21}$ or natural seawater from 
Tosa Bay, Japan. The medium using the artificial seawater contained the following elements (in mol L ${ }^{-1}$ ): $\mathrm{Mg}(\mathrm{II}), 5.6 \times 10^{-2}$; $\mathrm{Ca}(\mathrm{II}), 9.7 \times 10^{-3} ; \mathrm{Sr}(\mathrm{II}), 4.7 \times 10^{-5} ; \mathrm{Fe}(\mathrm{III}), 2.6 \times 10^{-5} ; \mathrm{Cu}(\mathrm{II})$, $7.9 \times 10^{-8} ; \mathrm{Zn}$ (II), $1.6 \times 10^{-7} ; \mathrm{Co}($ II) $), 8.4 \times 10^{-8} ; \mathrm{Mn}$ (II), $1.8 \times$ $10^{-6} ; \mathrm{Mo}(\mathrm{VI}), 5.2 \times 10^{-8}$. The medium using the natural seawater from Tosa Bay was prepared by adjusting to the same concentrations of these elements, except for $\mathrm{Co}$ and $\mathrm{Zn}\left(\mathrm{Co} ; 3.6 \times 10^{-7}\right.$ mol L ${ }^{-1}, \mathrm{Zn} ; 1.1 \times 10^{-6} \mathrm{~mol} \mathrm{~L}^{-1}$ ), after the concentrations originally contained in seawater were determined by a MAF-8HQ method. ${ }^{22}$

Large batch cultures were grown in 1-liter capacity vessels containing 1 liter of the sterilized Eppley's media, modified by the addition of $\mathrm{NaHCO}_{3}$. The inoculum of cells from the stock cultures was designed to give an initial cell density of 20 cells $\mathrm{mL}^{-1}$. Sterile air was introduced from the bottom of the vessel in which the contents were gently mixed. Experimental cultures were grown at $20{ }^{\circ} \mathrm{C}$ under a $12: 12 \mathrm{~h} \mathrm{~L} / \mathrm{D}$ photoperiod at a light intensity of $70 \mu \mathrm{mol}$ photon $\mathrm{m}^{-2} \mathrm{~s}^{-1}$ provided by cool white fluorescent lights. The cultures were run until the population reached a stationary phase of growth, usually 2-3 weeks. For dry-weight measurements of coccolithphores, the cells were centrifuged, washed and dried to a constant weight at $90{ }^{\circ} \mathrm{C}$. The amounts of coccoliths were estimated from the concentrations of particulate calcium $(>0.2 \mu \mathrm{m})$ in the cultures by assuming that the calcium particles consisted of $\mathrm{CaCO}_{3}$ of coccoliths. Under the batch conditions, 150-240 mg dry weight $\mathrm{L}^{-1}$ of E. huxleyi which included 79-120 mg $\mathrm{CaCO}_{3} \mathrm{~L}^{-1}$ of coccoliths was derived from the Eppley's cultures of the stationary phase. The organic tissue of the cells was calculated from the difference between dry weights of coccolithphores and $\mathrm{CaCO}_{3}$ of coccoliths. For measurements of the dissolved elements in the coccolithphore cultures, $100 \mathrm{~mL}$ of the cultures were filtered through $0.2-\mu \mathrm{m}$ Nuclepore filters (Costar) and acidified with $0.01 \mathrm{M}$ hydrochloric acid. The concentrations of the dissolved elements in the filtrates were estimated by a procedure of Sohrin et al. ${ }^{22,23}$

Purification of Coccolith Particles. The coccolithophore cells in culture medium were centrifuged at $10,000 \times \mathrm{g}$ for $10 \mathrm{~min}$, and the supernatant was discarded by decantation. The precipitate was resuspended in $45 \mathrm{~mL}$ of a $50 \mathrm{mM} \mathrm{NaHCO}$ aqueous solution, and the suspension was transferred to a $50-\mathrm{mL}$ centrifuge tube (polypropylene, Iwaki, Tokyo, Japan). The coccoliths were ultrasonically detached from the cells of E. huxleyi prior to coccolith purification. Sonication was performed for $1 \mathrm{~min}$ in an ultrasonic vibrator (frequency $42 \mathrm{kHZ}$, power $90 \mathrm{~W}$ ). The solution was then centrifuged at $3,000 \times \mathrm{g}$ for $30 \mathrm{~min}$. The precipitate was divided into two layers: cellular debris and coccoliths particles. The top layer, which consisted of the cellular debris, was removed by gently sucking up into a pipette. The bottom layer, which consisted of the coccolith particles, was resuspended with $10 \mathrm{ml}$ of $50 \mathrm{mM} \mathrm{NaHCO}$ aqueous solution, transferred to a $15-$ $\mathrm{mL}$ centrifuge tube (polypropylene, Iwaki, Tokyo, Japan), and centrifuged at $3,000 \times \mathrm{g}$ for $30 \mathrm{~min}$. This procedure was repeated three times. The precipitate was then washed with MQW to give a purified coccolith pellet. The final coccolith pellet was checked for cellular contamination by methyl green staining and examination under a light microscope. ${ }^{24}$

Determination of Minor and Trace Elements. After purification and drying, samples of approximately $10 \mathrm{mg}$ were dissolved in $50 \mathrm{~mL}$ of $0.5 \mathrm{M} \mathrm{HNO}_{3}$. For $\mathrm{Ca}, \mathrm{Mg}$ and $\mathrm{Sr}$ analyses, $10 \mathrm{~mL}$ of this mixture was analyzed by inductively coupled plasma atomic emission spectrometer (ICP-AES; ICAP-96-953,
Table 1. HR-ICP-MS Instrumental Parameters and Operating Conditions

\begin{tabular}{ll}
\hline $\begin{array}{l}\text { Plasma conditions } \\
\text { RF power }\end{array}$ & $1.2 \mathrm{~kW}$ \\
Reflected power & $<10 \mathrm{~W}$ \\
Argon flow rate & \\
Plasma gas & $14 \mathrm{~L} \mathrm{~min}^{-1}$ \\
Auxiliary gas & $1.0 \mathrm{~L} \mathrm{~min}^{-1}$ \\
Nebulizer gas & $1.0 \mathrm{~L} \mathrm{~min}^{-1}$ \\
Sampler & Copper \\
Skimmer & Copper \\
& \\
Data aquisition & \\
Measurement mode & $\mathrm{SIM} \mathrm{mode}$ \\
Sweep width & $6000 \mathrm{ppm}($ Resolution $=500)$ \\
& $600 \mathrm{ppm}($ Resolution $=6000)$ \\
Switching rate & $1000 \mathrm{~ms}$ \\
Repeated integration & 5 \\
Measurements per peak & 4 \\
& \\
Ultrasonic nebuliser settings & \\
Cooling temperature & $0{ }^{\circ} \mathrm{C}$ \\
Heating temperature & $140{ }^{\circ} \mathrm{C}$ \\
Solution uptake rate & $0.5 \mathrm{~mL}$ min $^{-1}$
\end{tabular}

Nippon Jarrel Ash, Kyoto, Japan). The remaining solution was diluted to the required dilution factors with $0.5 \mathrm{M} \mathrm{HNO}_{3}$, and introduced into a high-resolution inductively coupled plasma mass spectrometer (HR-ICP-MS; JMS-PLASMAX1, JEOL, Tokyo, Japan). An ultrasonic nebulizer (U-500AT, Cetac Technologes, Omaha, NE) was used for sample introduction, and a peristaltic pump (Minipuls II, Gilson Medical Electronics, Middleton, WI) was used to maintain the sample delivery rate to the nebulizer at $0.5 \mathrm{~mL} \mathrm{~min}^{-1}$. The operating condition and measurement parameters of HR-ICP-MS are summarized in Table 1. The ion lenses were optimized using ${ }^{89} \mathrm{Y}$ so that the count rate was relatively uniform across the mass range considered. Calibration lines were obtained using standard solutions containing $0.5 \quad \mathrm{M} \quad \mathrm{HNO}_{3}$ (TAMAPURE AA-100). It was assumed that the isotopic compositions of the elements were equal in the sample and standard solutions. The isotopes chosen for the determination are listed in Table 2. Each sample determination was the mean of 3-4 sequential determinations.

\section{Results and Discussion}

Choice of Reagents and Purification Procedures. The reagents and procedures used in coccolith purification were considered in view of previous work. ${ }^{17,24-27}$ Many workers have demonstrated that pellets of coccoliths can be obtained by density centrifugation through a colloidal silica and a sucrose solutons. On the other hand, Takano et al. separated large quantities of coccolith particles by collecting coccoliths floatated on solutions of $50 \mathrm{mM} \mathrm{NaHCO}$ aqueous solution. ${ }^{17}$ In the choice of a purification method in this study, particular emphasis was placed on preventing contamination by metals and coccolith dissolution throughout the procedure. For this reason, a $50 \mathrm{mM} \mathrm{NaHCO} 3$ aqueous solution was selected as the cleaning solution. We separated coccolith particles from 
Table 2. Limits of Detection in the Solid by HR-ICP-MS and ICP-AES

\begin{tabular}{|c|c|c|c|c|c|c|c|c|}
\hline \multirow{3}{*}{ Element } & \multicolumn{4}{|c|}{ HR-ICP-MS ${ }^{\text {a) }}$} & \multicolumn{4}{|c|}{$\overline{\text { ICP-AES }^{\mathrm{b})}}$} \\
\hline & \multirow[t]{2}{*}{ Isotope } & \multirow[t]{2}{*}{ Resolution } & \multicolumn{2}{|c|}{ Blank value/nmol $\mathrm{g}^{-1}$} & \multirow[t]{2}{*}{$\mathrm{LOD}^{\mathrm{c})} / \mathrm{nmol} \mathrm{g}^{-1}$} & \multicolumn{2}{|c|}{ Blank value/nmol g ${ }^{-1}$} & \multirow[t]{2}{*}{$\mathrm{LOD}^{\mathrm{c})} / \mathrm{nmol} \mathrm{g}^{-1}$} \\
\hline & & & Mean & $\mathrm{SD}$ & & Mean & $\mathrm{SD}$ & \\
\hline $\mathrm{Al}$ & 27 & 500 & 9.9 & 17 & 50 & & & \\
\hline As & 75 & 500 & 0.52 & 0.51 & 1.5 & & & \\
\hline $\mathrm{Ba}$ & 138 & 500 & 67 & 75 & 230 & & & \\
\hline Co & 59 & 500 & 5.7 & 1.2 & 3.5 & & & \\
\hline $\mathrm{Cr}$ & 52 & 6000 & 14 & 2.2 & 6.5 & & & \\
\hline $\mathrm{Fe}$ & 56 & 6000 & 37 & 17 & 51 & & & \\
\hline $\mathrm{Mg}$ & & & & & & 50 & 17 & 52 \\
\hline $\mathrm{Mn}$ & 55 & 500 & 1.8 & 1.3 & 3.8 & & & \\
\hline Mo & 95 & 500 & 2.1 & 0.21 & 0.64 & & & \\
\hline $\mathrm{Ni}$ & 58 & 6000 & 4.5 & 2.6 & 7.8 & & & \\
\hline $\mathrm{Sb}$ & 121 & 500 & 0.21 & 0.03 & 0.09 & & & \\
\hline $\mathrm{Sr}$ & & & & & & 30 & 16 & 47 \\
\hline $\mathrm{U}$ & 238 & 500 & 0.015 & 0.0003 & 0.001 & & & \\
\hline $\mathrm{V}$ & 51 & 6000 & 1.4 & 1.2 & 3.5 & & & \\
\hline W & 184 & 500 & 0.39 & 0.35 & 1.1 & & & \\
\hline $\mathrm{Y}$ & 89 & 500 & 0.016 & 0.003 & 0.01 & & & \\
\hline $\mathrm{Zn}$ & 64 & 6000 & 31 & 22 & 65 & & & \\
\hline
\end{tabular}

a) $\mathrm{DF}=5 \times 10^{4}$. b) $\mathrm{DF}=5 \times 10^{3}$. c) Limit of Detection throughout the procedure.

cellular debris by centrifugation using the difference in densities, by which method the coccolith particles and the organic tissue of cellular debris were precipitated quantitatively and layered. With the floatation method prescribed by Takano et al., significant contamination of cellular debris was observed in 20-30 mg of coccolith pellets, probably due to the scale of the coccolith samples. In our purification method, no cellular debris could be detected, after two cycles of resuspension and centrifugation.

Precision and Accuracy. The limits of detection (LODs) of the coccoliths analysis depend on contamination and adsorption on coccolith particles throughout the procedures, the instrumental sensitivity of HR-ICP-MS and the preparation of the final sample solution. For estimation of the LODs, the blank values of the analytical procedure were determined using $20.0 \mathrm{mg}$ of $\mathrm{CaCO}_{3}$ powder (less than $3 \mu \mathrm{m}$ diameter, $>99.99 \%$ of purity; Wako, Osaka, Japan) suspended in $50 \mathrm{~mL}$ of Eppley's media. The suspensions were treated in a similar manner to coccolithophore cultures. The recovery of $\mathrm{CaCO}_{3}$ powders ranged from 91 to $98 \%$ with an average of $94 \%$ for five determinations, which probably resulted from the dissolution of small $\mathrm{CaCO}_{3}$ powders in grain size. The resulting products of approximately $10 \mathrm{mg}$ were dissolved in $50 \mathrm{ml}$ of $0.5 \mathrm{M}$ $\mathrm{HNO}_{3}$ (a solid to solution dilution factor (DF) of $5 \times 10^{3}$ ). The solutions were further diluted for HR-ICP-MS determination. Analyses with less-diluted solutions were needed to increase the sensitivity of the determination for trace elements. Since the final solution which is introduced into HR-ICP-MS should be up to $20 \mathrm{mg} \mathrm{L}^{-1}$ of $\mathrm{CaCO}_{3}$ to prevent the interference of $\mathrm{Ca}^{2+}$, the lowest dilution factor was $5 \times 10^{4}$. The LODs, which were determined as three times the standard deviations of the blank values, are listed in Table 2. For analyses of As, $\mathrm{Cd}, \mathrm{Co}, \mathrm{Cr}, \mathrm{Mg}, \mathrm{Mn}, \mathrm{Mo}, \mathrm{Ni}, \mathrm{Sb}, \mathrm{Sr}, \mathrm{U}, \mathrm{V}, \mathrm{W}$ and $\mathrm{Y}$, the LODs throughout the procedure were almost equal to those of HR-
ICP-MS and ICP-AES, determined as three-times the standard deviations of the backgrounds for $0.5 \mathrm{M} \mathrm{HNO}_{3}$. The LODs throughout the procedure were $0.001-7.8 \mathrm{nmol} \mathrm{g}^{-1}$ for HRICP-MS with a $5 \times 10^{4}$ dilution factor and $30-50 \mathrm{nmol} \mathrm{g}^{-1}$ for ICP-AES with a $5 \times 10^{3}$ dilution factor. For analyses of $\mathrm{Al}$, $\mathrm{Ba}, \mathrm{Fe}$ and $\mathrm{Zn}$, both the means and the standard deviations of the blank values were higher than the values expected from the sensitivity of HR-ICP-MS. Although the LODs of 50-230 $\mathrm{nmol} \mathrm{g}^{-1}$ for $\mathrm{Al}, \mathrm{Ba}, \mathrm{Fe}$ and $\mathrm{Zn}$ are low enough to permit exact determinations in coccolith samples, further work is in progress to decrease the contamination during the procedures.

Table 3 gives the effects of the purification cycles on the contents of $\mathrm{Co}, \mathrm{Fe}, \mathrm{Mg}, \mathrm{Mn}, \mathrm{Mo}, \mathrm{Sr}$ and $\mathrm{Zn}$ in coccolith particles. The coccolith particles were prepared from $E$. huxleyi cultures of artificial seawater by the above procedure. Table 3 indicates that the concentrations of $\mathrm{Co}, \mathrm{Fe}, \mathrm{Mg}, \mathrm{Mn}, \mathrm{Mo}, \mathrm{Sr}$ and $\mathrm{Zn}$ in the coccolith particles were found to be relatively steady within three cycles of purification. Therefore, it is considered that the composition of elements in the coccolith particles are little changed by an undesirable side-process, such as dissolution and adsorption on the particle surfaces during the purification procedures.

Determination of Minor and Trace Elements in Coccoliths. The coccolith particles of E. huxleyi which were cultivated in modified Eppley's medium of natural seawater adding $\mathrm{NaHCO}_{3}$ were analyzed using the method described here. Figure 1 shows the amounts of coccolith particles and organic tissue produced by E. huxleyi, and dissolved calcium concentrations in the media after 20 days cultivation. The productivity of coccoliths increased with the increases in the $\mathrm{NaHCO}_{3}$ concentration in the modified Eppley's medium, although the produced organic tissue of the cells remained almost constant. The amount of coccolith particles in the medium adding $20 \mathrm{mM} \mathrm{NaHCO}{ }_{3}$ was ten-times higher than that in the standard 
Table 3. Effects of the Purification Cycles on Concentrations of Minor and Trace Elements in Coccolith Particles ${ }^{\text {a) }}$

\begin{tabular}{llll}
\hline Element & $\begin{array}{l}\text { Purification cycle } \\
1 / \mathrm{nmol} \mathrm{g}^{-1}\end{array}$ & $2 / \mathrm{nmol} \mathrm{g}^{-1}$ & $3 / \mathrm{nmol} \mathrm{g}^{-1}$ \\
\hline $\mathrm{Co}$ & 21 & 23 & 25 \\
$\mathrm{Fe}$ & 8100 & 8300 & 7800 \\
$\mathrm{Mg}$ & 7400 & 7200 & 7100 \\
$\mathrm{Mn}$ & 220 & 230 & 200 \\
$\mathrm{Mo}$ & $\mathrm{ND}^{\mathrm{b})}$ & $\mathrm{ND}^{\mathrm{b})}$ & $\mathrm{ND}^{\mathrm{b})}$ \\
$\mathrm{Sr}$ & 28000 & 30000 & 29000 \\
$\mathrm{Zn}$ & 2400 & 2600 & 2600 \\
\hline
\end{tabular}

a) Coccolith particles were prepared from Emiliania huxleyi cultures in Eppley's media using natural seawater from Tosa Bay, Japan. b) Not detected.

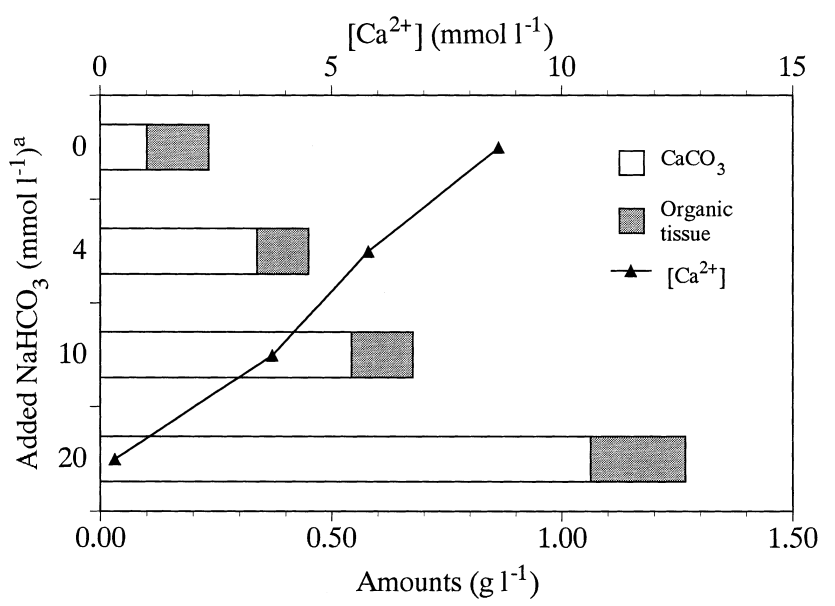

Fig. 1. Amounts of production by E. huxleyi in modified Eppley's medium using natural seawater from Tosa Bay, Japan. [Ca] represents the concentration of $\mathrm{Ca}^{2+}$ in the medium after 20 days' cultivation. ${ }^{\text {a }}$ The standard Eppley's medium contains $1.8 \mathrm{mM}$ of bicarbonate.

Eppley's medium. The dissolved calcium concentration markedly decreased from $9.5 \mathrm{mM}$ initially to $0.31 \mathrm{mM}$. The concentrations of the other elements in the media are listed in Table 4. Initially, the medium contain various elements which are due to natural seawater from Tosa Bay and further addition of Eppley's metals, as described in Experimental Section. The concentrations of $\mathrm{Al}, \mathrm{Cd}, \mathrm{Cr}, \mathrm{Fe}, \mathrm{Mn}, \mathrm{Mo}$ and $\mathrm{Sr}$ decreased with the production of coccoliths during the cultivation, while those of $\mathrm{Co}$ and $\mathrm{Mg}$ were almost constant.

Compositions of the minor and trace elements in the coccolith particles are presented in Fig. 2. It was found that the LODs achieved by the applied procedure were sufficiently low to determine the concentrations of $\mathrm{Al}, \mathrm{Ba}, \mathrm{Ca}, \mathrm{Co}, \mathrm{Cr}, \mathrm{Fe}, \mathrm{Mg}$, $\mathrm{Mn}, \mathrm{Mo}, \mathrm{Sr}$ and $\mathrm{Zn}$ in the cultivated coccoliths. Analyte elements were divided into three groups with respect to the relation to coccolith production by E. huxleyi. First, alkaline earth elements, such as $\mathrm{Mg}$ and $\mathrm{Sr}$ in coccolith particles, increased with the amount of coccoliths production in the culture medi-

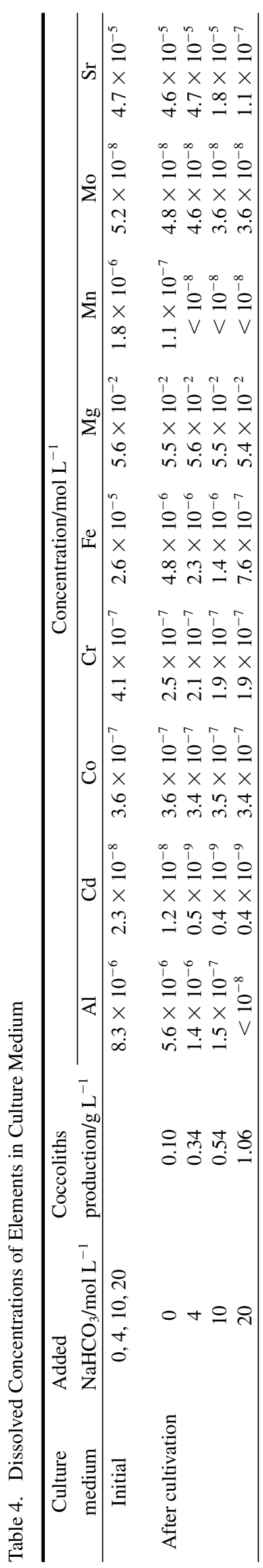


um. This relationship would be attributable to the decrement of the $\mathrm{Ca}^{2+}$ concentration in the medium and the formation of alkaline earth carbonates of $\mathrm{Mg}$ and $\mathrm{Sr}$. Secondly, the concentrations of $\mathrm{Fe}, \mathrm{Mn}, \mathrm{Al}, \mathrm{Cr}, \mathrm{Cd}$ and $\mathrm{Mo}$ in the coccolith particles decreased with the production of coccoliths. The dissolved concentrations of these elements decreased in the medium, which was probably due to incorporation into organic tissue of coccolithophores, the precipitation of slightly soluble species and adsorption onto particle surfaces. In particular, dissolved $\mathrm{Fe}, \mathrm{Mn}$ and $\mathrm{Al}$ are readily removed from the water column owing to their poor solubility in oxic seawater. ${ }^{28}$ Thirdly, only minor changes were noted in the compositions of Co in coccoliths.

It must be noted that the compositions of elements in the culture media varied during cultivation. The data concerning $\mathrm{M} / \mathrm{Ca}$ in Fig. 2 are unsatisfactory to estmate the partition coefficients of the minor and trace elements. However, it seems reasonable to suppose that the element variations in the coccolith particles are caused by variations in the compositions of the elements in the growth media.

\section{Conclusion}

We have described a method for the determination of minor and trace elements below $\mu \mathrm{mol} \mathrm{g}^{-1}$ levels in coccolith particles of coccolithophores by the combination of a clean centrifugation technique and HR-ICP-MS measurements. The procedure developed in this work could be applied to the purification of more than $20 \mathrm{mg}$ of coccoliths with sufficiently low contaminations. The analytical results of coccolithophore cultures suggested that the compositions of minor and trace elements in coccoliths are influenced by the cultivation medium. This analytical method will be available for a better interpretation of carbonate biogeochemistry in the environment.

We sincerely thank Dr M. Okazaki, Department of Science Education, Tokyo Gakugei University, for supplying the algae cultures. This research was partly supported by a Grant-in-Aid for Encouragement of Young Scientists (14780441) from the Ministry of Education, Science, Sports and Culture, and the Steel Industry Foundation for the Advancement of Environmental Protection Technology.
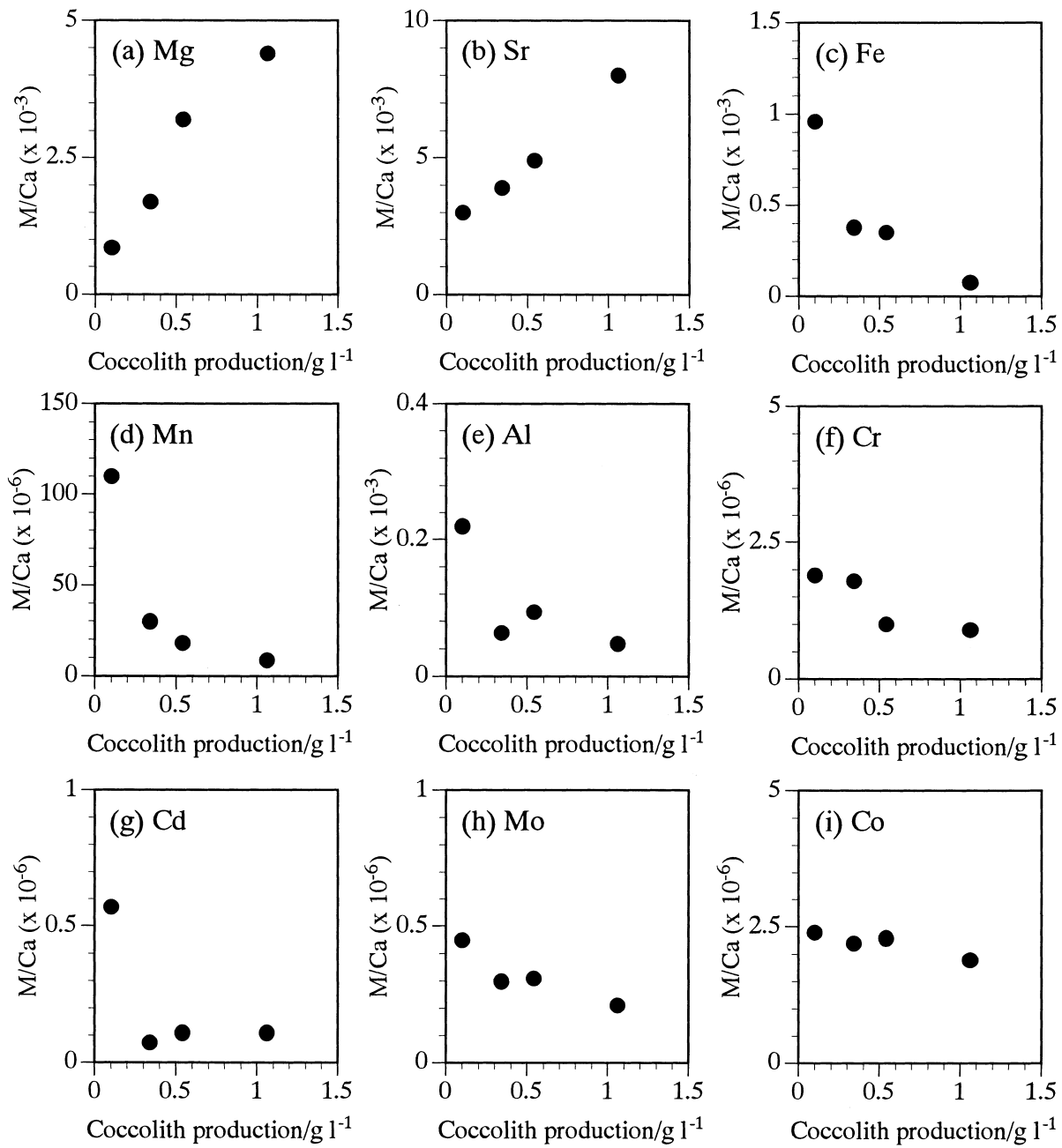

Fig. 2. Molar ratios of minor and trace elements to calcium in coccolith particles of Emiliania huxleyi. The culture conditions were reported in Fig. 1. 


\section{References}

1 J. W. Morse and F. T. Mackenzie, "Geochemistry of Sedimentary Carbonates," Elsevier (1990).

2 W. Stumm and J. J. Morgan, "Aquatic Chemistry, 3rd ed," Wiley Interscience, New York (1996).

3 E. A. Boyle, Geochim. Cosmochim. Acta, 50, 265 (1986).

4 D. W. Lea, T. A. Mashiotta, and H. J. Spero, Geochim. Cosmochim. Acta, 63, 2369 (1999).

5 G. D. Rosenberg, "Skeletal Growth of Aquatic Organisms," ed by D. C. Rhoads and R. A. Lutz, Plenum Press, New York (1980), pp. 133.

6 R. T. Klein, K. C. Lohmann, and C. W. Thayer, Geochim. Cosmochim. Acta, 60, 4207 (1996).

7 E. V. Putten, F. Dehairs, E. Keppens, and W. Baeyens, Geochim. Cosmochim. Acta, 64, 997 (2000).

8 J. W. Morse, Mar. Chem., 20, 91 (1986).

9 M. Temmam, J. Paquette, and H. Vali, Geochim. Cosmochim. Acta, 64, 2417 (2000).

10 S. Honjo, J. Mar. Res., 36, 469 (1978).

11 S. Honjo, S. J. Manganini, and J. J. Cole, Deep-Sea Res., 29, 609 (1982).

12 J. D. Milliman, Global Biogeochemical Cycles, 7, 927 (1993).

13 E. Buitenhuis, J. van Bleijswijk, D. Bakker, and M. Veldhuis, Mar. Ecol. Prog. Ser., 143, 271 (1996).

14 E. Paasche, Nature, 193, 1094 (1962).

15 P. Westbroek and J. R. Young, P. Protozool, 36, 368 (1989).

16 J. R. Young, in "Coccolithophores," ed by A. Winter and W. G. Siesser, Cambridge University Press, U. K. (1994), pp.
1161.

17 H. Takano, E. Manabe, M. Hirano, M. Okazaki, J. G. Burgess, N. Nakamura, and T. Matsunaga, Appl. Biochem. Biotechnol., 39/40, 239 (1993).

18 H. M. Stoll and D. P. Schrag, Geochemistry Geophysics Geosystems, 1, 1999GC000015 (2000).

19 H. Okada and A. McIntyre, Micropaleontology, 23, 1 (1977).

20 R. W. Eppley, R. W. Holmes, and J. D. H. Strickland, J. Exp. Marine Biol. and Ecol., 1, 191 (1967).

21 J. Lyman and R. H. Fleming, J. Mar. Res., 3, 134 (1940).

22 Y. Sohrin, K. Ueda, S. Iwamoto, S. Akiyama, H. Hasegawa, M. Matsui, T. Fujita, T. Kugii, S. Goda, H. Obata, and E. Nakayama, Anal. Chim. Acta, 363, 11 (1998).

23 Y. Fujishima, Y. Sohrin, K. Ueda, H. Hasegawa, and M. Matsui, in "Proceedings of the International Symposium Kanazawa, 1999: Earth-Water-Humans," Kanazawa, Kanazawa University (1999), pp. 85.

24 E. W. De Jong, L. Bosch, and P. Westbroek, Eur. J. Biochem., 70, 611 (1976).

25 E. Paasche and S. Brubac, Phycologia, 33, 324 (1994).

26 H. Takano, R. Takei, E. Manabe, J. G. Burgess, M. Hirano, and T. Matsunaga, Appl. Microbiol. Biotechnol., 43, 460 (1995).

27 M. Okazaki, T. Sato, N. Mutho, N. Wada, and T. Umegaki, J. Mar. Biotechnol, 6, 16 (1998).

28 F. M. M. Morel and J. G. Hering, "Principles and Applications of Aquatic Chemistry," Wiley Interscience, New York (1993). 